\title{
IMPLEMENTASI PENERBITAN AKTA KELAHIRAN BAGI ANAK-ANAK TERLANTAR DI KOTA DENPASAR
}

\author{
Anak Agung Sagung Nandya Pramesti, Ida Ayu Putu Widiati, I Nyoman Sutama \\ Fakultas Ilmu Hukum Universitas Warmadewa, Denpasar - Bali, Indonesia \\ Nandyapramestie@gmail.com, widiati_dayu@yahoo.co.id, sutamainyoman62@gmail.com
}

\begin{abstract}
Abstrak
Kota Denpasar sebagai daerah Ibukota Provinsi Bali saat ini berjuang untuk mengatasi permasalahan anak terlantar. Data dari Dinas Sosial Kota Denpasar tercatat pada tahun 2019 terdapat 14 panti asuhan dengan anak asuh 470 orang. Penelitian ini bertujuan untuk mengetahui bagaimanakah langkah-langkah untuk mendapatkan akta kelahiran bagi anak terlantar di Kota Denpasar dan bagaimanakah dampak dari akta kelahiran bagi anak terlantar. Hasil penelitian ini menunjukan bahwa bagi anak-anak terlantar di Kota Denpasar untuk mendapatkan Akta Kelahiran telah memiliki dasar hukum yang diatur dalam peraturan perundang-undangan yang berlaku sesuai dengan ketentuan-ketentuan yang mengatur mengenai akta kelahiran anak terlantar. Dinas Kependudukan dan Catatan Sipil Kota Denpasar telah menerbitkan akta kelahiran bagi semua anak- anak terlantar yang dimohonkan oleh panti asuhan tempat mereka bernaung. Anak- anak terlantar yang telah mendapatkan Akta Kelahiran akan berdampak kepada hak identitas mereka akan terpenuhi.
\end{abstract}

Kata kunci: Akta kelahiran, Anak terlantar

\begin{abstract}
Denpasar City as the capital of Bali Province is currently struggling to solve the problem of neglected children. Data from the Denpasar City Social Service recorded that in 2019 there were 14 orphanages with 470 foster children. This study aims to determine how are the steps to obtain birth certificates for neglected children in Denpasar City and how the impact of birth certificates on neglected children. The results of this study indicated that for neglected children in Denpasar City to get a birth certificate has a legal basis which is regulated in the applicable laws and regulations in accordance with the provisions governing the birth certificate of neglected children. The Department of Population and Civil Registry of Denpasar City has issued birth certificates for all neglected children who have been applied for by the orphanage where they live. Neglected children who have received a birth certificate will have an impact on their right to identity.
\end{abstract}

Keywords: Birth certificate, Neglected child

\section{PENDAHULUAN}

Pertambahan penduduk yang cepat dalam suatu negara akan menyebabkan beban bagi negara tersebut yang akan berdampak bertambahnya keluarga miskin. Kemiskinan akan menyebabkan munculnya kriminalitas, pengemis dan akan menyebabkan bertambahnya anak-anak terlantar di perkotaan (Astri, 2014; Ihsan, 2016). Mereka akan menempati ruang-ruang kosong ataupun fasilitas-fasilitas sosial yang akan menyebabkan perkotaan menjadi kumuh. Anak-anak jalanan berhak untuk hidup dan berkembang sebagai manusia yang mempunyai harkat dan martabat yang harus mendapatkan perlindungan hukum dari pemerintah. Anak terlantar banyak terlibat dalam pelanggaran hukum dikarenakan mereka kurang berpendidikan. Hal ini sering dimanfaatkan oleh oknum-oknum tertentu untuk keuntungan mereka sendiri. Anak merupakan generasi penerus dari suatu bangsa dan negara wajib untuk melindungi dan memberikan ruang seluas-luasnya untuk tumbuh dan berkembang.

Anak adalah seseorang yang belum dewasa atau belum mengalami masa pubertas yang berkembang dari bayi hingga mencapai usia 18 tahun dan belum menikah. Anak merupakan anugerah dari Tuhan Yang Maha Esa bagi keluarganya Mereka berhak memperoleh perlakuan yang adil dan terhindar dari hal-hal yang mencelakakannya. Orang tua akan menjaga dan merawat anak tersebut dengan penuh kasih sayang. Tidak ada orang tua menginginkan anaknya terlantar, tetapi dengan perkembangan teknologi dan pembangunan yang semakin pesat menimbulkan ekses negatif pada masyarakat (Nasution, 2016). 
Pergaulan dalam era milenial ini menyebabkan adanya anak diluar nikah yang tidak diinginkan oleh orang tuanya. Keadaan ini membuat mereka melakukan hal-hal di luar hukum yang berakibat anak yang dilahirkan akan terlantar karena adanya tekanan ekonomi menimbulkan masalah pada anak yang dilahirkan yang tidak mampu dipelihara oleh orang tuanya dengan baik (Siregar, Kusumah, \& Yayasan Lembaga Bantuan Hukum Indonesia, 1986). Keadaan ini akan mengakibatkan anak tersebut akan menjadi terlantar. Tanpa adanya pengawasan dan perlindungan dari orang tuanya akan mengakibatkan anak-anak ini akan mengalami kesulitan dalam melangsungkan hidupnya.

Untuk memberikan perlindungan kepada seorang anak untuk tumbuh kembangnya maka pemerintah telah mengatur melalui perundang-undangan yaitu Undang-undang Nomor 4 Tahun 1979 Tentang Kesejahteraan anak. Hak-hak anak untuk mendapatkan pendidikan kesehatan dan jaminan sosial akan terhambat apabila mereka tidak mempunyai identitas yang jelas. Anak- anak terlantar yang tidak mempunyai orang tua untuk mengurus pertumbuhan dan perkembangannya, maka akan sulit untuk mendapatkan identitas diri (Setiawan, 2017). Setiap penduduk berhak memperoleh dokumen kependudukan pelayanan yang sama perlindungan dan kepastian hukum termasuk anak-anak terlantar.

Peningkatan jumlah penduduk yang tinggi membawa dampak yang negatif bagi daerah perkotaan seperti banyaknya pengangguran, merebaknya pekerja sektor informal, kriminalitas meningkat, pengemis, dan gelandangan (Zefianningsih, Wibhawa, \& Rachim, 2017). Pulau Bali yang merupakan daerah tujuan wisata mendapat beban yang cukup berat dengan datangnya penduduk/migrasi maupun pertumbuhan penduduk yang sangat cepat yang berdampak pada ekonomi sosial dan budaya. Masalah klasik yang dihadapi oleh daerah perkotaan adalah urbanisasi yang menyebabkan terjadinya berbagai masalah-masalah sosial termasuk adanya anak-anak terlantar. Kota Denpasar sebagai daerah ibu kota Provinsi Bali saat ini juga berjuang untuk mengatasi permasalahan anak terlantar. Anak-anak terlantar di perkotaan semakin bertambah seiring dengan perkembangan teknologi. Mereka berasal dari berbagai macam kultur atau daerah untuk mencari penghidupan yang lebih layak, namun mereka menjadi beban daerah perkotaan Keberadaan mereka menjadi perhatian pemerintah maupun pihak-pihak yang peduli terhadap masalah kemanusiaan. Anak-anak terlantar ini sebagian mereka ada pada panti-panti asuhan yang dikelola oleh yayasan-yayasan yang peduli akan permasalahan sosial di perkotaan. Data dari Dinas sosial Kota Denpasar tercatat pada tahun 2019 terdapat 14 panti asuhan dengan anak asuh 470 orang.

Berdasarkan uraian di atas, penelitian ini dilakukan dengan tujuan mengungkap bagaimanakah langkah-langkah untuk mendapatkan akta kelahiran bagi anak terlantar di Kota Denpasar dan bagaimanakah dampak dari akta kelahiran bagi anak terlantar.

\section{METODE PENELITIAN}

Penelitian ini menggunakan metode penelitian hukum empiris. Dalam penelitian ini informasi dikumpulkan secara langsung melalui wawancara dengan pihak terkait dan mengamati secara seksama pada objek penelitian. Dalam rangka memperoleh data yang relevan, teknik pengumpulan data dengan metode pencatatan dan studi lapangan dilakukan. Informasi yang telah dikumpulkan diolah dan dilakukan pengkajian melalui studi kepustakaan, yaitu dengan membandingkan hasil yang diperoleh dilapangan dengan peraturan-peraturan ataupun pendapat-pendapat yang ada dalam literatur. Data yang sudah terkumpul dianalisis secara deskriptif dan disajikan menggunakan metode informal.

\section{HASIL PENELITIAN DAN PEMBAHASAN}

Anak-anak perlu mendapatkan perlindungan karena mereka belum mengenal akan kehidupan. Perlindungan anak ini mereka dapatkan dari masih dalam kandungan oleh orang tuanya. Perlindungan hukum bagi anak-anak sudah diatur dalam peraturan perundang-undangan. Menurut (Saraswati, 2015) bahwa undang-undang harus memberikan perlindungan kepada anak berdasarkan pada asas non diskriminasi asas kepentingan yang terbaik bagi anak asas hak untuk hidup kelangsungan hidup dan perkembangan serta asas penghargaan terhadap pandangan/pendapat anak. Setiap anak berhak atas perlindungan oleh orang tua keluarga masyarakat dan negara. Dalam undang-undang diatur tentang hak anak yaitu anak berhak atas pemeliharaan perlindungan kesejahteraan perawatan asuhan dan bimbingan berdasarkan kasih sayang dalam keluarganya maupun di dalam asuhan untuk tumbuh dan berkembang dengan wajar.

Perlindungan hukum adalah berbagai upaya hukum yang harus diberikan oleh aparat penegak hukum untuk memberikan rasa aman baik secara pikiran maupun fisik dari gangguan dan berbagai 
ancaman dari pihak manapun (Raharjo, 2000). Perlindungan Hukum merupakan perlindungan oleh hukum saja. Perlindungan hukum yang diberikan kepada manusia sebagai subyek hukum terkait dengan hak dan kewajibannya dengan sesama manusia maupun lingkungannya. Sebagai subyek hukum manusia memiliki hak dan kewajiban untuk melakukan suatu tindakan hukum. Perlindungan hukum kepada masyarakat merupakan tindakan atau upaya untuk melindungi masyarakat dari tindakan sewenang-wenang oleh orang lain ataupun penguasa yang bertentangan dengan hukum untuk mewujudkan ketertiban dan ketentraman sehingga masyarakat dapat melangsungkan kehidupannya dengan aman dan damai.

Perlindungan hukum yang diberikan kepada anak-anak terlantar sebagai subyek hukum untuk memenuhi akan hak-hak untuk tumbuh dan berkembang tanpa adanya tindakan diskriminatif. Anakanak terlantar agar bisa menjadi subyek hukum mereka harus mempunyai identitas diri dan tercatat dalam administrasi kependudukan. Negara memberikan perlindungan hukum bagi anak-anak terlantar. Perlindungan hukum ini tertuang dalam Undang-Undang Dasar 1945 yaitu fakir miskin dan anak-anak terlantar dipelihara oleh Negara. Hal ini diartikan bahwa negara mempunyai kewajiban untuk memelihara dan melindungi serta bertanggung jawab terhadap kelangsungan hidup dari anak-anak terlantar.

Pencatatan kelahiran/akta kelahiran merupakan perwujudan hak sipil pertama kali yang diakui oleh Negara. Hak-haknya sebagai subyek hukum tidak akan bisa diterima apabila seseorang tidak mempunyai identitas diri yang tercatat pada akta kelahirannya. Identitas diri seseorang dapat dilihat dengan adanya akta kelahiran otentik yang dikeluarkan oleh pejabat yang berwenang. Akta kelahiran sangat penting bagi seseorang termasuk anak terlantar yang tidak diketahui identitas dan asal usul orang tuanya akta kelahiran merupakan bentuk pengakuan negara atas status keperdataannya.

Anak yang terlantar apabila sudah ada pencatatan kelahiran, maka negara sudah memberikan pengakuan hukum terhadap identitas silsilah dan kewarganegaraan yang diwujudkan melalui dokumen pencatatan kelahiran yaitu akta kelahiran (Nurbayanti, Rofiandri, \& Novitarini, 2003). Anak terlantar sangat perlu untuk didahulukan dalam memperoleh akta kelahiran dibandingkan dengan anak - anak pada umumnya karena anak terlantar tidak memiliki perlindungan dari orang tua sehingga sangat rentan terhadap suatu tindak kejahatan. Akta kelahiran sangat penting bagi anak terlantar untuk meminimalisir adanya suatu tindak kejahatan yang disebabkan karena tidak mempunyai akta kelahiran sebagai identitas diri. Dengan mempunyai akta kelahiran seseorang akan mendapatkan akses pendidikan kesehatan pelayanan publik dan mendapatkan jaminan sosial.

Peristiwa kelahiran seseorang akan dicatat dalam suatu akta pencatatan yang disebut dengan. Akta kelahiran menurut Waluyadi (2009) Akta kelahiran sangat penting dimiliki oleh setiap orang karena merupakan pengakuan resmi dari negara atas keberadaan sebagai warga Negara Salah satu perwujudan adanya hak atas identitas adalah adanya akte kelahiran. Masih banyak anak-anak di Indonesia belum mempunyai akta kelahiran yang merupakan satu bukti bahwa seorang anak telah mempunyai hak identitas sebagai anak termasuk anak-anak terlantar, sehingga secara de jure keberadaan anak yang tidak mempunyai akta kelahiran dianggap tidak ada oleh negara.

Pemberian akta kelahiran adalah suatu bentuk kewajiban Negara untuk memberikan perlindungan dan pengakuan terhadap penentuan status pribadi dan status hukum setiap peristiwa kelahiran yang dialami oleh penduduk termasuk perlindungan terhadap hak anak yang berada di dalam dan/atau di luar wilayah Negara Kesatuan Republik Indonesia. Hak identitas diberikan oleh Negara melalui administrasi kependudukan yaitu akta kelahiran diberikan segera setelah anak itu lahir secara gratis. Hak-hak asasi manusia harus dihargai dihormati dan dijunjung tinggi oleh Negara. Hak asasi manusia merupakan hak dasar yang secara kodrati melekat pada diri manusia bersifat universal dan langgeng oleh karena itu harus dilindungi dihormati dipertahankan dan tidak boleh diabaikan dikurangi atau dirampas oleh siapapun.

Salah satu perwujudan adanya hak atas identitas adalah adanya akta kelahiran. Pembuatan akta kelahiran telah diatur berdasarkan UU Nomor 23 Tahun 2006 tentang Administrasi Kependudukan sebagaimana telah diubah dengan UU Nomor 24 Tahun 2013 dinyatakan bahwa setiap kelahiran wajib dilaporkan oleh penduduk kepada instansi pelaksana dan pejabat pencatatan sipil akan mencatat pada. Register Akta Kelahiran dan menerbitkan Kutipan Akta Kelahiran. Setiap warga negara wajib mencatatkan kelahirannya dengan mengajukan terjadinya peristiwa kelahiran seorang anak kepada instansi yang berwenang untuk mencatatkan kelahirannya agar dapat memiliki akta kelahiran dan apabila tidak melaporkannya akan diberikan sanksi denda. Pembuatan akta kelahiran telah diatur 
dalam perundang-undangan yang bertujuan agar setiap warga negara memiliki akta kelahiran yang akan dipergunakan untuk mendapatkan hak-hak pelayanan publik pendidikan kesehatan perlindungan dan jaminan sosial. Pemerintah dalam melaksanakan pelayanan publik kepada masyarakat tanpa adanya perlakuan yang diskriminatif.

Permohonan untuk mendapatkan akta kelahiran di Kota Denpasar mengacu kepada Permendagri Nomor 11 Tahun 2010 tentang Pedoman Pendataan dan Penerbitan Dokumen Kependudukan Bagi Penduduk Rentan Administrasi Kependudukan, Permendagri No 9 Tahun 2016 tentang Percepatan Peningkatan Cakupan Kepemilikan Akta Kelahiran maka pengurusan akta kelahiran bagi anak-anak terlantar yang telah bernaung kepada panti asuhan ataupun Yayasan, persyaratan KK masih tetap berlaku hanya saja mereka dimasukkan dalam Kartu Keluarga Panti Asuhan atau Yayasan dengan kepala keluarga adalah kepala panti/ atau Yayasan.

Berdasarkan hasil wawancara dengan ibu Anak Agung Ayu Diah Kurniawati S.Pt., M Si Kepala Bidang Rehabilitasi Sosial Dinas Sosial Kota Denpasar pada tahun 2019 tercatat Anak-anak terlantar di kota Denpasar yang berjumlah 2000 orang yang keberadaannya di panti Asuhan dan di Yayasan Di Kota Denpasar terdapat 14 panti asuhan dengan anak asuh sejumlah 470 anak. Berdasarkan hasil survei yang dilaksanakan, hanya sebagian kecil anak di panti asuhan belum mempunyai Akta Kelahiran. Hal ini disebabkan karena sebagian besar panti asuhan masih belum memasukkan anak tersebut di dalam kartu keluarga panti asuhan yang merupakan satu persyaratan yang harus dipenuhi dalam pengurusan akta kelahiran. Akta kelahiran yang diterbitkan melalui program dispensasi yaitu program yang umumnya baru dilaksanakan setelah anak berumur lebih dari satu tahun.

Program dispensasi di Kota Denpasar telah dijalankan walaupun beberapa persyaratan memperoleh akta kelahiran bagi anak yang dibutuhkan belum sempurna dan anak tersebut sudah mendapatkan akta kelahiran dan sebagai walinya adalah pimpinan Yayasan atau panti asuhan. Tidak adanya akta kelahiran akan berdampak kepada hak-hak identitas anak yaitu hak pendidikan kesehatan maupun jaminan sosial. Dengan tidak mempunyai dokumen identitas diri banyak anak-anak yang terjerumus dalam tindakan kriminalitas dan dimanfaatkan oleh orang-orang yang tidak bertanggungjawab.

Berdasarkan Permendagri 9 tahun 2016 tentang Percepatan Peningkatan Cakupan Kepemilikan Akta Kelahiran. Peristiwa kependudukan yang penting termasuk peristiwa kelahiran harus dilaporkan kepada pihak berwenang. Pihak berwenang akan mencatat/membuat Register Akta Kelahiran yang mencatat mengenai peristiwa kelahiran yang diterbitkan dan ditandatangani oleh pejabat berwenang berdasarkan ketentuan peraturan perundang-undangan. Yang selanjutnya akan membuat Kutipan Akta Kelahiran yaitu kutipan data outentik yang dipetik sebagian dari register akta kelahiran diterbitkan dan ditandatangani oleh pejabat berwenang berdasarkan ketentuan peraturan perundang-undangan dan kutipan ini yang diserahkan kepada pihak pemohon. Setiap peristiwa kelahiran harus didaftarkan di Kantor Catatan Sipil agar mendapatkan akta kelahiran sebagai bukti yang sah mengenai status kewarganegaraan dan identitas seseorang. Pendaftaran ini memerlukan data - data lengkap suatu peristiwa kelahiran untuk dapat membuat akta kelahiran dan data - data tersebut yang akan dimasukkan dalam akta kelahiran yang dimohonkan. Jika tidak ada data - data lengkap sebagai syarat untuk membuat akta kelahiran maka pembuatan akta kelahiran tidak dapat dilakukan.

Sebelum tahun 2016 pengurusan akta kelahiran bagi anak terlantar terbentur dengan salah satu persyaratan yang harus dipenuhi yaitu mengurus Berita Acara Pemeriksaan (BAP) asal-usul anakanak terlantar dari Kepolisian yang pelaksanaannya memerlukan waktu dan tenaga sehingga pihak yayasan atau panti asuhan enggan mengurus akta kelahiran bagi anak- anak asuhannya. Dengan melihat permasalahan seperti itu, maka pemerintah menerbitkan peraturan untuk memudahkan pihak panti asuhan dan yayasan untuk mengurus akta kelahiran. Dalam peraturan tersebut dinyatakan bahwa pihak penanggung jawab yaitu panti asuhan atau yayasan tidak perlu lagi mengurus BAP asal-usul anak terlantar dari kepolisian cukup dengan membuat SPTJM kebenaran data kelahiran yang ditandatangani oleh wali/penanggung jawab (Permendagri No 9 Tahun 2016). Surat Pernyataan Tanggung Jawab Mutlak (SPTJM) merupakan surat pernyataan yang dibuat oleh panti asuhan tentang data kelahiran anak yang diurus akta kelahirannya dan diketahui oleh dua orang saksi Panti asuhan menganggap ketentuan ini sangat memudahkan bagi pihak panti asuhan untuk mengurus pencatatan kelahiran/akta kelahiran untuk anak-anak terlantar yang ada dalam asuhannya. Berdasarkan Permendagri Nomor 11 Tahun 2010 tentang Pedoman Pendataan dan Penerbitan Dokumen 
Kependudukan Bagi Penduduk Rentan Administrasi Kependudukan Permendagri No 9 Tahun 2016 tentang Percepatan Peningkatan Cakupan Kepemilikan Akta Kelahiran di Kota Denpasar. Akta kelahiran diterbitkan dalam 3 kategori yaitu Akta kelahiran umum akta kelahiran terlambat dan akta kelahiran seorang ibu. Dengan status hukum yaitu anak pasangan suami istri dari perkawinan yang sah anak seorang ibu serta anak yang tidak diketahui asal-usul atau keberadaan orang tuanya. Bagi anakanak tidak diketahui asal-usul atau keberadaan orang tuanya maka diperlukan Berita Acara Pemeriksaan (BAP) asal-usul anak- anak terlantar dari Kepolisian atau Surat Pernyataan Tanggung Jawab Mutlak (SPTJM) kebenaran data kelahiran yang ditandatangani oleh pengurus atau penanggung jawab dalam konteks ini panti asuhan.

Kota Denpasar telah menerapkan peraturan pemerintah tentang Administrasi Kependudukan yang akan mencatatkan kelahiran untuk mendapatkan Akta Kelahiran Persyaratan untuk mendapatkan akta tersebut adalah sebagai berikut:

a) Akta Kelahiran Umum : (Pelaporan Sampai 60 Hari setelah Kelahiran) yaitu sebagai berikut : mengisi formulir permohonan akta kelahiran (F-201) Surat Keterangan Asli Kelahiran Dokter/Bidan yang menolong, Surat Keterangan Asli Kelahiran Kepala Desa/Lurah, Fotocopy Akta Perkawinan orang tua Fotocopy, KK + KTP kedua orang tua + dua saksi.

b) Akta Kelahiran Terlambat : (Melampaui batas waktu lewat 60 hari sejak kelahiran) yaitu sebagai berikut : sama dengan Kelahiran Umum butir 1 sampai dengan 5 Mengisi formulir pernyataan orang tua bermaterai Rp 6000 - yang menyatakan kelahiran terlambat Dengan persetujuan dari Kepala Instansi Pelaksana Setempat.

c) Akta Kelahiran Anak Seorang Ibu yaitu sebagai berikut : Mengisi formulir permohonan akta kelahiran (F-2 01), Surat Keterangan Asli Kelahiran Dokter/Bidan yang menolong, Surat Keterangan Asli Kelahiran Kepala Desa/Lurah, Fotocopy Akta Kelahiran Ibu (jika tidak ada bisa menyertakan Ijazah Ibu), Fotocopy KK + KTP orang tua + dua saksi, Mengisi formulir pernyataan Ibu bermeterai Rp 6000 - (apabila kelahiran melampaui batas waktu lewat 60 hari sejak kelahiran, Mengisi formulir pernyataan orang tua bermaterai Rp 6000 - tentang tidak keberatannya anak tersebut dicatatkan sebagai Anak Seorang Ibu Dengan persetujuan dari Kepala Instansi Pelaksana Setempat (apabila kelahiran melampaui batas waktu lewat 60 hari sejak kelahiran).

Dari hasil wawancara dengan Ibu Dra Pande Made Sri Artatik M Si Kepala Bidang Pelayanan Pencatatan Sipil Dinas Kependudukan dan Catatan Sipil Kota Denpasar pada prinsipnya pelayanan pencatatan sipil termasuk pembuatan akta kelahiran bagi setiap orang adalah sama perlakuannya Di Kota Denpasar pelayanan publik dilaksanakan melalui satu pintu yaitu melalui Mal Pelayanan Publik Kota Denpasar Graha Sewaka Dharma. Pendaftaran pengurusan akta kelahiran akan disampaikan pada Mal Pelayanan Publik Kota Denpasar dengan membawa persyaratan-persyaratan yang telah diinformasikan kepada masyarakat melalui pamflet maupun digital.

Setelah dilakukan verifikasi oleh Dinas Kependudukan dan Pencatatan Sipil, apabila persyaratan belum lengkap, maka pemohon akan diberikan informasi untuk melengkapi kekurangan persyaratan yang dimaksud. Apabila hasil verifikasi lengkap maka Dinas Kependudukan dan Pencatatan Sipil akan mencetak akta kelahiran yang dimohonkan. Secara umum persyaratan untuk mengurus akta kelahiran adalah surat kelahiran dari dokter atau bidan maupun penolong kelahiran dua nama dan identitas saksi kelahiran KK orang tua KTP orang tua dan kutipan akta nikah atau akta kelahiran orang tua Untuk anak-anak terlantar pengurusan akta kelahiran dilakukan oleh pihak panti asuhan/yayasan dengan melampirkan persyaratan yang telah diatur dalam perundang-undangan.

Sepanjang persyaratan sesuai dengan perundang-undangan telah terpenuhi maka akan diterbitkan dokumen akta kelahirannya. Akta kelahiran bagi anak-anak terlantar di kota Denpasar dapat diterbitkan dengan perlakuan yang sama dengan anak-anak pada umumnya. Pembuatan akta kelahiran bagi anak terlantar sudah mempunyai dasar-dasar hukum yaitu UU Nomor 23 Tahun 2006 tentang Administrasi Kependudukan sebagaimana telah diubah dengan UU Nomor 24 Tahun 2013 Permendagri Nomor 11 Tahun 2010 tentang Pedoman Pendataan dan Penerbitan Dokumen Kependudukan Bagi Penduduk Rentan Administrasi Kependudukan dan Permendagri No 9 Tahun 2016 tentang Percepatan Peningkatan Cakupan Kepemilikan Akta Kelahiran.

Akta kelahiran yang sudah dimiliki oleh anak-anak terlantar di kota Denpasar telah dimanfaatkan untuk mendapatkan akses pendidikan pelayanan kesehatan pelayanan publik dan 
jaminan sosial. Anak-anak terlantar di kota Denpasar yang berada dalam panti asuhan maupun yayasan akan dapat tumbuh dan berkembang menyongsong kehidupan yang lebih baik sebagai generasi penerus dan berguna bagi nusa dan bangsa.

Dengan perkembangan teknologi informasi yang sangat cepat, Pemerintah Pusat melalui Direktorat Jenderal Kependudukan dan Pencatatan Sipil Kementerian Dalam Negeri membuat program administrasi kependudukan melalui sistem online. Percontohan program ini salah satunya diberikan kepada Pemerintah Kota Denpasar melalui Dinas Kependudukan dan Pencatatan Sipil Kota Denpasar yang meluncurkan mesin Anjungan Dukcapil Mandiri (ADM) sebagai mesin pelayanan masyarakat dalam bidang pencatatan sipil Mesin ADM ini diharapkan dapat mempercepat proses pelayanan publik khususnya administrasi kependudukan yang akan dapat memangkas proses birokrasi pembuatan surat-surat pencatatan sipil. Dengan adanya mesin ini masyarakat tidak lagi menunda pengurusan pembuatan surat-surat pencatatan sipil. Mesin ini juga dapat meminimalkan potensi terjadinya penyalahgunaan jabatan hingga korupsi.

\section{SIMPULAN DAN SARAN}

\section{Simpulan}

Berdasarkan hasil dan pembahasan yang telah diuraikan di atas, ada beberapa simpulan yang dapat dibuat, yaitu: pertama, anak-anak terlantar yang tidak memiliki akta kelahiran akan berdampak kepada tidak diterimanya hak-hak sipil seperti tidak diakui keberadaannya di negara RI, tidak mendapatkan jaminan sosial kesehatan pendidikan dan rentan terhadap eksploitasi anak, ataupun trafficking/perdagangan anak. Kedua, Dinas Kependudukan dan Catatan Sipil Kota Denpasar telah menerbitkan akta kelahiran bagi semua anak-anak terlantar yang dimohonkan oleh panti asuhan tempat mereka bernaung.

\section{Saran}

Selain itu, ada beberapa saran yang perlu disampaikan berdasarkan hasil penelitian ini, yaitu: pertama, untuk yayasan dan panti asuhan agar memenuhi peraturan pemerintah tentang adminduk sehingga anak-anak asuhannya mendapatkan perlindungan hukum. Kedua, untuk pemerintah agar meningkatkan pelayanan Adminduk terutama pada anak-anak terlantar atau penduduk rentan.

\section{DAFTAR PUSTAKA}

Astri, H. (2014). Kehidupan Anak Jalanan di Indonesia: Faktor Penyebab, Tatanan Hidup dan Kerentanan Berperilaku Menyimpang. Aspirasi, 5(2), 145-155.

Ihsan, K. (2016). Faktor Penyebab Anak Melakukan Tindakan Kriminal (Studi Kasus Lembaga Pemasyarakatan Pekanbaru Kelas II B). JOM FISIP, 3(2), 1-15.

Nasution, R. D. (2016). Pengaruh Kesenjangan Digital terhadap Pembangunan Pedesaan (Rural Development). Jurnal Penelitian Komunikasi Dan Opini Publik, 20(1), 31-44.

Nurbayanti, H. S., Rofiandri, R., \& Novitarini, W. (2003). Publikasi Hak Masyarakat dalam Bidang Identitas. Jakarta: Pusat Studi Hukum \& Kebijakan Indonesia.

Raharjo, S. (2000). Ilmu Hukum. Bandung: PT. Citra Aditya Bakti.

Saraswati, R. (2015). Hukum Perlindungan Anak di Indonesia (2nd ed.). Bandung: Citra Aditya Bakti.

Setiawan, H. H. (2017). Akta Kelahiran sebagai Hak Identitas Diri Kewarganegaraan Anak. Sosio Informa, 3(1), 26-39.

Siregar, B., Kusumah, M. W., \& Yayasan Lembaga Bantuan Hukum Indonesia. (1986). Hukum dan hak-hak anak. Jakarta: Yayasan LBH Indonesia bekerja sama dengan C.V. Rajawali.

Waluyadi. (2009). Hukum Perlindungan Anak. Bandung: Mandar Maju.

Zefianningsih, B. D., Wibhawa, B., \& Rachim, H. A. (2017). Penanggulangan Gelandangan dan Pengemis oleh Panti Sosial Bina Karya "Pangudi Luhur" Bekasi. RISET \& PKM, 3(1), 9-18. 